\title{
Importance of Knowledge Management in Establishing Organization Strategy: Study on Saudi Arabian Airlines HR Division, Jeddah
}

\author{
Khalil Yaghi ${ }^{1} \&$ Yaser Omar Sindi ${ }^{1}$ \\ ${ }^{1}$ Information Science Department, King Abdulaziz University, Jeddah, KSA \\ Correspondence: Khalil Yaghi, Information Science Department, King Abdulaziz University, Jeddah, KSA. Tel: \\ 966-560-299-639. E-mail: kaahmad1@kau.edu.sa
}

Received: December 9, 2016

Accepted: February 15, 2016

Online Published: February 25, 2016

doi:10.5539/ijbm.v11n3p235

URL: http://dx.doi.org/10.5539/ijbm.v11n3p235

\begin{abstract}
This study was aimed at determining the awareness of the Saudi Arabian Airlines (Saudia) human resources (HR) division employees about the role of knowledge management in the company. In addition, their understanding of the concept of knowledge management was also evaluated. Further, the degree to which knowledge management processes were practically employed by the HR employees in the company was also determined. A descriptive and analytical course was employed as a proper method in this study. The study sample was selected from Saudi employees working in Jeddah; owing to their large number, a random sample of 60 employees was chosen. The questionnaire method was employed in this study, and several results were obtained. Some of the main results are as follows. The system encouraged the participants to follow the best practices of other organizations and ensure that managers understand that successful knowledge depends on organizational culture. Further, knowledge management is considered as information management, and study participations agreed to some extent to the knowledge management concept for HR employees. In addition, it was pointed out that good and creative ideas for improving competitive advantage are supported and an individual and group initiative culture is spread between employees.
\end{abstract}

Keywords: knowledge management, knowledge management processes, organizational strategy, organization culture, human resources

\section{Introduction}

Information technology (IT) has played a significant role in bringing about economic transformation and social growth, as well as a comprehensive change in almost all aspects of life. It is now regarded as the most important element in production and investment. Moreover, it generates large revenues for many countries and costs high for many others. The cost of IT includes the costs of equipment, tools, software, systems, maintenance, and training. Recently, advanced technology has become very important for us, and one of our primary uses of technology is to manage our knowledge. Knowledge is represented by human experience (Donovan, 2008), values, beliefs, and skills; these are regarded as important elements in an age that derives its name from its identification - the knowledge age. Indeed, knowledge today is an indispensable source used by organizations in production and provision of their services (Bontis, 1999).

According to (Hegazy, 2005, p. 11), "Knowledge management is regarded as one of the most important strategy and modern administrative methods to make change, development and achieve the competitive feature. Its importance has been proved in industry, health and production."

In addition, (Negm, 2004, p. 709) stated that knowledge is a new origin and the newest production factor recognized as the main source of competitive features in management.

Owing to the various concerns of organizations, economies, and societies employing knowledge management - which involves many challenges, especially in development and competition fields - this study is an attempt to demonstrate the importance of knowledge management in establishing organizational strategy.

(Al- Qubaisi, 2011), on the basis of his perspective of knowledge, states that it has contributed to enabling an organization to reset its goals. Moreover, the increasing awareness about the role of knowledge has motivated researchers to identify their intellectual frame, depending on inputs, strategies, samples, and operations of management. Further, he adds that the role played by knowledge in the progress of organizations is expanding; 
moreover, knowledge is increasingly contributing to converting these organizations into part of a new global economy known as the knowledge economy.

\subsection{Problems and Questionnaires Used in This Study}

The issue of knowledge application by many organizations is analyzed from two perspectives. The first one focuses on technical tools, means, and methods where the financial implications of knowledge management become important; thus, this perspective is concerned with short-term factors. In contrast, the second perspective focuses on methods, approaches, and social and strategic events that demonstrate the human approach to knowledge management (Hislop, 2003). Therefore, this perspective focuses on the long-term vision.

On the basis of these perspectives and considering the significant role played by knowledge management in many organizational aspects (e.g., supporting skills and competition, improving production and performance, assisting decision making, establishing value, and encouraging innovation) (Mehrdad, 2011), the central problem of this study was to determine the role of knowledge management in establishing organizational strategy. To determine the scope of the problem, the following questions were formulated:

1) What is the importance of the stages of establishing, acquiring, organizing, and using information in knowledge management?

2) What is the importance of strategy bases in applying knowledge management?

3) Is there any relation between strategic bases and the knowledge management process?

\subsection{Significance of This Study}

This study is very significant as it addresses a key issue related to the human resources (HR) division of the Saudi Arabian airlines (Saudia). This issue can be explained as follows. The HR division represents an environment for which development and innovation are main features; therefore, it is essential to focus upon these features. Knowledge management is a means to achieve this. Therefore, understanding the importance of knowledge and managing it correctly is a goal that individuals and societies seek to achieve.

In this regard, (Ghareeb, 2000, p. 10) stated, "All calls for releasing thinking, granting freedom for knowledge, making the opportunity for innovation and creation available in the age when the knowledge importance is one of the important factors of success. So, the knowledge management imposes itself strongly on the arena due to the development of knowledge fields and the escalation of its importance."

Further, (Al-Sabagh, 2002, p. 16) opined, "The knowledge management is involved in many social events, or in other meaning, it has become an effective power that all societies use to achieve its progress on others or at least become on an equal basis; technically, scientifically and cultural with these societies. The knowledge management provides many opportunities for organizations in the progressive societies in order to achieve the competitive progress through the creation of new techniques, production means and work methods which contribute in reducing costs and increasing profits and all of this can be called "Knowledge Industry" that becomes recently an essential topic in the most progressive societies."

(Bryson, 2003) stated that participation, communication, and exchange of knowledge among employees play a significant role in establishing organizational strategy. Moreover, these processes contribute to reconciling interests and contradictive values and create a good method that help in decision making and successful execution of processes based on the organization's vision and message.

From a practical viewpoint, this study is very significant owing to the low number of local researches and studies that address the possibility of the development of Saudia by using knowledge management processes. In addition, this study would be regarded as a small study conducted in the kingdom of Saudi Arabia that addressed the topic of knowledge management. Therefore, this study can be a guideline for the employees of Saudia. In addition, it is expected that the results obtained in this study would assist employees and officials in the kingdom in taking necessary measures to develop and achieve the country's goals.

\subsection{Goals}

1) Determine the extent of awareness of the HR division employees about the importance of knowledge management in an organization.

2) Determine the extent of awareness of the HR division employees about the concept of knowledge management in an organization.

3) Determine the extent of understanding of the HR division employees of the practices of knowledge management processes in an organization. 


\subsection{Describe Relevant Scholarship}

1) Bayad and Smen (2003): "Knowledge management: Reality and prospects"

This study involved an analysis of the concept of the existence of knowledge management borders that were investigated in several studies. The aim of this study was to track the development of this initiative and included various initiatives. Researchers focused on four main attitudes. In addition, they referred to initiatives aimed at setting a knowledge management system in organizations based on two types of strategies: first that is based on HR, which depends upon personal knowledge, and second that is based on information, which depends on codified knowledge. On the basis of this information, both researchers thought that the development path of knowledge management depends on the development and enhancement attitudes of personal and codified knowledge. This knowledge itself depends on the dynamic interactions between implicit and virtual knowledge both in an individual and collective manner. These knowledge types are explained in the Halazon model of knowledge proposed by Nonka and Takeuchi; this model can be regarded as a foundation to establish additional value in an organization.

Therefore, efforts for establishing knowledge management should be mobilized on an organizational level according to the following four main attitudes: encouragement of production, formation and contribution of knowledge through regulative learning via dialogue and discussions, sharing of experiences; and several interactions in the work field. Moreover, knowledge should be acquired by searching within contexts, implementing data and data systems for knowledge, regulating the organization's memory and date, using appropriate tools and methods that ensure the improvement of knowledge management, such as assistive programs for decision making, skill management programs, and administration systems for best practices. Finally, best use should be made of abilities afforded by communication and IT systems in order to exchange knowledge through the establishment of societies within several networks by employing the available technical methods as a collective work program.

2) (Randall, 2008): "Identifying the knowledge processes: Study the adoption of team, behavioral and motive machinery and leadership processes"

This study was conducted at Florida University, Miami. It was aimed at (1) identifying knowledge, behavioral, and motive processes that foster the adoption of a team with unexpected changes and sudden events, and (2) describing team and leadership processes that result in achieving these operations. Results indicated that the knowledge capacity of a team and the work required to achieve these goals by collective participation instead of the team leader's role were related. Moreover, the quality of mental methods and strategies employed by team members (emergent knowledge cases) and the extent of exchanging information among team members (behavioral process) were also related. Teams with high-quality mental models and similar high information levels were found to have a high capacity to behave and adapt with changes in their surroundings. In addition, they showed higher levels of effective decision making.

3) (Ba and Leona 2004): "Knowledge management and institutional culture: Social point of view"

This study was carried out at the George Washington University. It was aimed at investigating the relation between knowledge management and institutional culture. In this study, institutional education systems and competitive values frames were employed. The institutional cultures investigated in the study indicated that there were many strong, meditative, and weak cultures. Further, results indicated that the highest culture had the highest degree of knowledge management and performance.

4) Al-Fares study, Suleiman: "Master about the role of knowledge management in rising efficiency of organization performance" (field study on the conversion industries and organizations in Damascus)

This study was aimed at determining the role of knowledge management in improving the performance level in an organization. The study involved 10 modern companies. An analytical descriptive approach was used to collect data. A typical sample consisted of (42 industrial organizations working in the food, textile, and clothing sectors in Damascus (all were medium and large organizations with employees not less than 25).

The study included general managers, directors of administrations, heads of divisions, and specialists from the 10 organizations.

It was concluded that there is a strong relation between knowledge management and performance. On the basis of this relation, the researcher formed applicable results that in turn allowed him to provide recommendations that could effectively and efficiently contribute to improving the regulative and technical performance of the investigated organizations and all similar organizations. 
5) Al-Sharfa study, Salwa: "Master about the role of knowledge management and information technology in achieving competitive benefits in the existing banks in Gaza"

This study was aimed at determining the role of knowledge management and IT in achieving competitive benefits in the existing banks in Gaza.

An analytical descriptive approach was applied in this study, and a questionnaire was distributed to all general managers and heads of divisions in the related banks. The sample consisted of 174 employees.

The following results were found in this study:

-The existing banks in Gaza used a knowledge management system in all units and divisions. They used communication and IT systems, as well as the skills and experiences of human beings and their knowledge about development and renaissance to attain adequate connection with the surroundings. In addition, they used this knowledge to realize development aided by advanced technology and information.

-A separate regulative unit or special division for managing knowledge and IT was not present in any of the banks in Gaza. However, knowledge management and IT systems were operational in the banks.

This study included the following recommendations:

-The awareness and understanding of bank officials about hard challenges, continuous obstacles, and intensive competition they are expected to face in Gaza both presently and in the future should be increased.

-Bank officials in Gaza should pay more attention to knowledge management; moreover, they should work toward establishing a definite administrative framework to manage knowledge and IT.

6) Boaacha study, Mubarak and Bin Mansour Lelia: "A research of knowledge management as a modern administrative attitude in the age of globalization"

This study was aimed at identifying the elements of knowledge management and its importance. An analytical descriptive approach was employed in this study. The following results were obtained:

-Knowledge management is necessary for the stability of organizations and also maintains their competitive strength. Therefore, knowledge management is essential for organizations in order to regulate, use, maintain, and develop the abilities of their employees.

-Knowledge management is a necessary strategy rather than an optional one among other strategies that an organization employs owing to rapid changes in the information field where the existence of knowledge management affords a significant advantage. Without knowledge, no organization can continue and survive.

The following recommendations were made in this study:

-Modern organizations should review their traditional functions in a knowledge frame. In other words, there should be a new job called "knowledge management job."

-Organizations should provide knowledge on a wider basis. This means that data, information, and knowledge systems should be developed to enable employees to use them. Moreover, systems that facilitate acquiring knowledge and identifying its sources should be developed.

-A supportive technical infrastructure for knowledge management processes should be provided.

-Higher administrators in organizations should pay more attention to knowledge management in order to improve HR efficiency and general performance level.

\section{Methodology}

A descriptive method was used in this study. This method is one of the most important methods and the most frequently used in researches; therefore, it was the most suitable for this study. This method can be used to describe and explain facts and define real circumstances, as well as to define common and prevailing practices. It is a method that can be used to describe and explain a particular phenomenon. The study sample consisted of HR employees working in Saudia, Jeddah, in the year 1435 AH/2014 AD.

\subsection{Study Sampling}

The study sample consisted of 55 employees from the HR division in Saudia, Jeddah, in the year 1435 AH/2014 $\mathrm{AD}$. They were the ones who received a questionnaire, 60 of which were distributed. The questionnaire was used as a tool in this study for collecting relevant data and information because of its nature regarding its targets, methodology, and community. This tool was prepared on the basis of on the following factors:

1) The theoretical part in the subject of knowledge management in defining organization strategies. 
2) Studies used in the field of knowledge management.

\subsubsection{Stages of Questionnaire Building}

The construction of the study tool involved several steps to make it field-ready by reviewing the research literature as follows:

First step: defining the target of the study tool, i.e., measuring the impact of knowledge management in defining organizational strategies.

Second step: defining the measurement aspects of the study tool by dividing the study tool into four dimensions as follows:

1) Establishing the HR division in Saudia

2) The concept of knowledge management concerning HR employees

3) Knowledge management operations

4) The concept of knowledge organization in addition to its evaluation regarding HR employees

Third step: distributing the questionnaire in its final state. The questionnaire in its final state is distributed to the study sample (60 employees in the HR sector in Jeddah).

2.1.2 Authenticity of Data Collection Tool

Cronbach's alpha was used for estimating the consistency coefficient by applying it to a random sample that consisted of 16 employees, equal to $20 \%$ of the total study sample. Cronbach's alpha was estimated by SPSS that reached 0.937 , as shown in Table 1 . This result confirmed the reliability of the research tool used for data collection. Depending on the results, the practical implications of the statistical analysis of data and the ability of generalizing the results were determined.

Table 1. Cronbach's alpha

\begin{tabular}{ll}
\hline Axis & Cronbach's alpha \\
\hline HR division in Saudia work on & 0.959 \\
Concept of knowledge management regarding HR employees & 0.910 \\
Knowledge management operations & 0.957 \\
Concept of organizing and estimating knowledge concerning HR employees & 0.954 \\
\hline
\end{tabular}

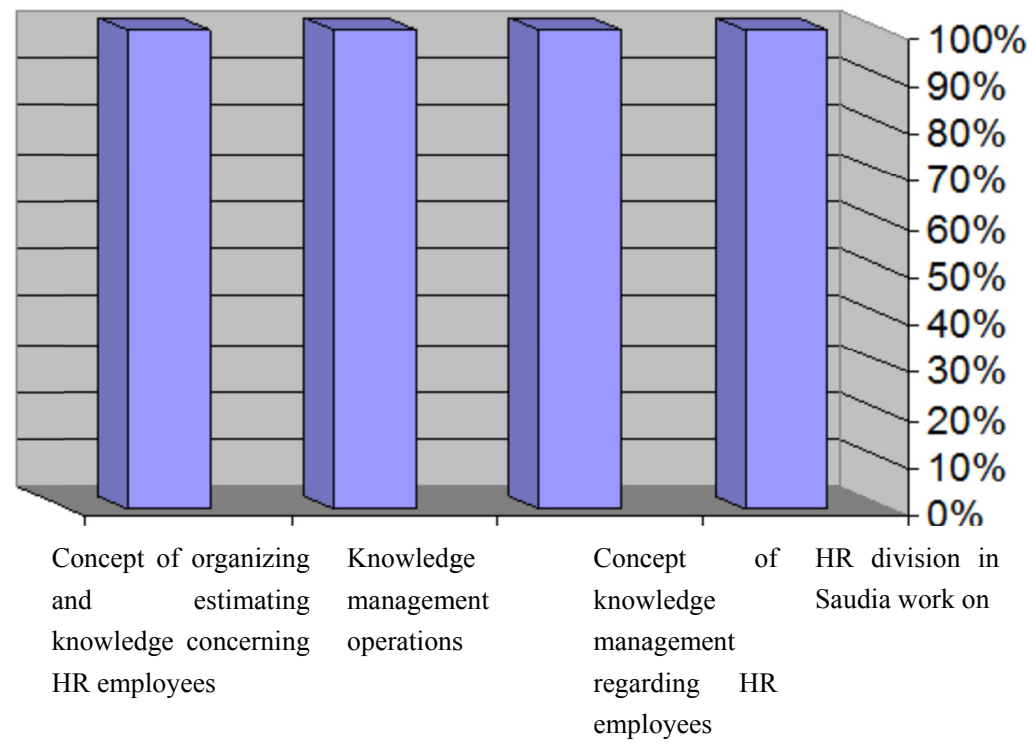

Figure 1. Cronbach's alpha coefficient 
Moreover, for defining the attitudes of individuals while answering the questions of the main study, every answer was provided a weight and an extent as shown in the following table:

Table 2. Statistical

\begin{tabular}{lll}
\hline Categories & Weight & Value of weighted mean \\
\hline Totally disagree & 1 & $1-1.80$ \\
Disagree & 2 & $1.80-2.60$ \\
Fairly agree & 3 & $2.60-3.40$ \\
Agree & 4 & $3.40-4.20$ \\
Totally agree & 5 & $4.20-5$ \\
\hline
\end{tabular}

For defining the categories to which an individual belonged, the level of acceptance and prevailing opinion for every statement was defined according to the value of the weighted mean of sample answers as follows:

Table 3. Different percentages, repetitions, arithmetic means, and standard deviations of the axis (work of HR division in Saudia)

\begin{tabular}{|c|c|c|c|c|c|c|c|c|c|c|c|c|c|c|}
\hline \multirow[t]{2}{*}{$\begin{array}{l}\text { Serial } \\
\text { number }\end{array}$} & \multirow[t]{2}{*}{$\begin{array}{l}\text { Agreement } \\
\text { level }\end{array}$} & \multirow[t]{2}{*}{$\begin{array}{l}\text { The } \\
\text { Standard } \\
\text { deviation }\end{array}$} & \multirow[t]{2}{*}{ Mean } & \multicolumn{2}{|c|}{$\begin{array}{l}\text { Totally } \\
\text { disagree }\end{array}$} & \multicolumn{2}{|c|}{ Disagree } & \multicolumn{2}{|l|}{$\begin{array}{l}\text { Fairly } \\
\text { agree }\end{array}$} & \multicolumn{2}{|c|}{ Agree } & \multicolumn{2}{|c|}{$\begin{array}{l}\text { Totally } \\
\text { agree }\end{array}$} & \multirow[t]{2}{*}{ Statement } \\
\hline & & & & $\%$ & $\mathrm{~T}$ & $\%$ & $\mathrm{~T}$ & $\%$ & $\mathrm{~T}$ & $\%$ & $\mathrm{~T}$ & $\%$ & $\mathrm{~T}$ & \\
\hline 3 & $\begin{array}{l}\text { Fairly } \\
\text { agree }\end{array}$ & 1.16 & 3.25 & 18.2 & 10 & 23.6 & 13 & 27.3 & 15 & 27.3 & 15 & 3.6 & 2 & $\begin{array}{lr}\text { Giving } & \text { opinions } \\
\text { toward } & \text { knowledge } \\
\text { issues } & \end{array}$ \\
\hline 7 & $\begin{array}{l}\text { Fairly } \\
\text { agree }\end{array}$ & 1.31 & 3.00 & 20.0 & 11 & 10.9 & 6 & 30.9 & 17 & 25.5 & 14 & 12.7 & 7 & $\begin{array}{l}\text { Providing a suitable } \\
\text { budget to support } \\
\text { knowledge projects }\end{array}$ \\
\hline 4 & $\begin{array}{l}\text { Fairly } \\
\text { agree }\end{array}$ & 1.18 & 3.15 & 9.1 & 5 & 18.2 & 10 & 38.2 & 21 & 18.2 & 10 & 16.4 & 9 & $\begin{array}{l}\text { A system trying to } \\
\text { avoid rules and } \\
\text { regulations that hinder } \\
\text { the application of } \\
\text { knowledge } \\
\text { management }\end{array}$ \\
\hline 2 & $\begin{array}{l}\text { Fairly } \\
\text { agree }\end{array}$ & 1.02 & 3.25 & 3.6 & 2 & 18.2 & 10 & 40.0 & 22 & 25.5 & 14 & 12.7 & 7 & $\begin{array}{l}\text { A system verifying } \\
\text { most of the procedures } \\
\text { for applying } \\
\text { knowledge } \\
\text { management } \\
\text { operations }\end{array}$ \\
\hline 1 & Agree & 1.18 & 3.47 & 5.5 & 3 & 18.2 & 10 & 21.8 & 12 & 32.7 & 18 & 21.8 & 12 & $\begin{array}{l}\text { A system trying to } \\
\text { encourage users to } \\
\text { imitate best practices } \\
\text { of other organizations }\end{array}$ \\
\hline 5 & $\begin{array}{l}\text { Fairly } \\
\text { agree }\end{array}$ & 1.33 & 3.15 & 14.5 & 8 & 14.5 & 8 & 34.5 & 19 & 14.5 & 8 & 21.8 & 12 & $\begin{array}{l}\text { A system trying to } \\
\text { provide users with } \\
\text { suitable information } \\
\text { about knowledge } \\
\text { management during } \\
\text { training }\end{array}$ \\
\hline 6 & $\begin{array}{l}\text { Fairly } \\
\text { agree }\end{array}$ & 1.43 & 3.05 & 16.4 & 9 & 21.8 & 12 & 29.1 & 16 & 5.5 & 3 & 27.3 & 15 & $\begin{array}{l}\text { A system trying to } \\
\text { effectively encourage } \\
\text { users to participate } \\
\text { with other users in } \\
\text { decision-making } \\
\text { operations }\end{array}$ \\
\hline
\end{tabular}

Table 3 shows the percentages, repetitions, arithmetic means, and standard deviations of the HR division axis in 
Saudia. On the basis of the average arithmetic mean that reached 3.19, it was concluded that the study participants fairly agree with the statements of this axis.

The statements were regressively arranged on the basis of the arithmetic mean for every statement. It was found that the statement "A system trying to encourage users to imitate best practices of other organizations" corresponds to the highest mean (3.47) and the prevailing opinion was "agree." Further, the statement "Providing a suitable budget to support knowledge projects" corresponds to the smallest mean (3.00) and the prevailing opinion was "fairly agree."

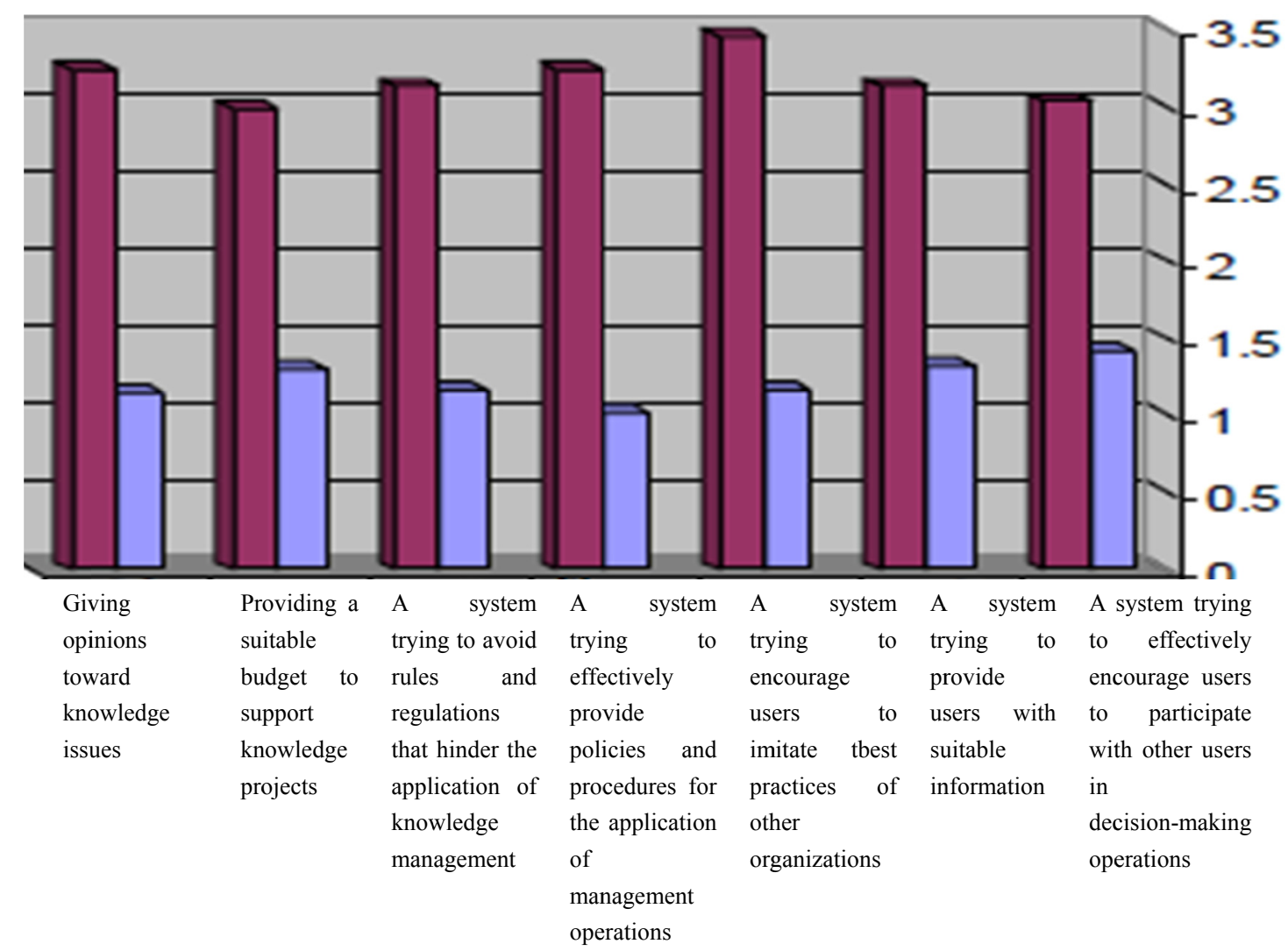

Figure 2. Arithmetic means and standard deviations for axis (work of HR division in Saudia)

Table 4. Different percentages, repetitions, arithmetic means, and standard deviations for axis (concept of knowledge management of HR employees)

\begin{tabular}{|c|c|c|c|c|c|c|c|c|c|c|c|c|c|c|}
\hline \multirow[t]{2}{*}{ Statement } & \multicolumn{2}{|c|}{$\begin{array}{l}\text { Totally } \\
\text { agree }\end{array}$} & \multicolumn{2}{|c|}{ Agree } & \multicolumn{2}{|c|}{$\begin{array}{l}\text { Fairly } \\
\text { agree }\end{array}$} & \multicolumn{2}{|c|}{ Disagree } & \multicolumn{2}{|c|}{$\begin{array}{l}\text { Totally } \\
\text { disagree }\end{array}$} & \multirow[t]{2}{*}{ Mean } & \multirow[t]{2}{*}{$\begin{array}{l}\text { The } \\
\text { Standard } \\
\text { deviation }\end{array}$} & \multirow[t]{2}{*}{$\begin{array}{l}\text { Agreement } \\
\text { level }\end{array}$} & \multirow[t]{2}{*}{$\begin{array}{l}\text { Serial } \\
\text { number }\end{array}$} \\
\hline & $\mathrm{T}$ & $\%$ & $\mathrm{~T}$ & $\%$ & $\mathrm{~T}$ & $\%$ & $\mathrm{~T}$ & $\%$ & $\mathrm{~T}$ & $\%$ & & & & \\
\hline $\begin{array}{l}\text { The term knowledge } \\
\text { management is } \\
\text { intensively transferred }\end{array}$ & & & 11 & 20.0 & 18 & 32.7 & 17 & 30.9 & 9 & 16.4 & 2.57 & 0.99 & Disagree & 5 \\
\hline $\begin{array}{l}\text { Knowledge } \\
\text { management } \\
\text { considered } \\
\text { information } \\
\text { management }\end{array}$ & 4 & 7.3 & 14 & 25.5 & 27 & 49.1 & 5 & 9.1 & 5 & 9.1 & 3.13 & 1.00 & $\begin{array}{l}\text { Fairly } \\
\text { agree }\end{array}$ & 2 \\
\hline $\begin{array}{l}\text { A strategy is made for } \\
\text { applying knowledge } \\
\text { management }\end{array}$ & 6 & 10.9 & 12 & 21.8 & 18 & 32.7 & 15 & 27.3 & 4 & 7.3 & 3.02 & 1.11 & $\begin{array}{l}\text { Fairly } \\
\text { agree }\end{array}$ & 3 \\
\hline Giving a priority for & 7 & 12.7 & 11 & 20.0 & 12 & 21.8 & 20 & 36.4 & 5 & 9.1 & 2.91 & 1.21 & Fairly & 4 \\
\hline
\end{tabular}


applying knowledge

management

operations

Directors believe that

the success of

knowledge

management depends

on organizational

culture agree

$\begin{array}{llllllllllllll}11 & 20.0 & 17 & 30.9 & 18 & 32.7 & 4 & 7.3 & 5 & 9.1 & 3.45 & 1.17 & \text { Agree } & 1\end{array}$


Table 5. Different percentages, repetitions, arithmetic means, and standard deviations for axis (knowledge management operations)

\begin{tabular}{|c|c|c|c|c|c|c|c|c|c|c|c|c|c|c|}
\hline \multirow[t]{3}{*}{ Statement } & \multirow{2}{*}{\multicolumn{2}{|c|}{$\begin{array}{l}\text { Totally } \\
\text { agree }\end{array}$}} & \multirow{2}{*}{\multicolumn{2}{|c|}{ Agree }} & \multirow{2}{*}{\multicolumn{2}{|c|}{$\begin{array}{l}\text { Fairly } \\
\text { agree }\end{array}$}} & \multirow{2}{*}{\multicolumn{2}{|c|}{ Disagree }} & \multirow{2}{*}{\multicolumn{2}{|c|}{$\begin{array}{l}\text { Totally } \\
\text { disagree }\end{array}$}} & \multirow{3}{*}{ Mean } & \multirow{3}{*}{$\begin{array}{l}\text { The } \\
\text { Standard } \\
\text { deviation }\end{array}$} & \multirow{3}{*}{$\begin{array}{l}\text { Agreement } \\
\text { level }\end{array}$} & \multirow{3}{*}{$\begin{array}{l}\text { Serial } \\
\text { number }\end{array}$} \\
\hline & & & & & & & & & & & & & & \\
\hline & $\mathrm{T}$ & $\%$ & $\mathrm{~T}$ & $\%$ & $\mathrm{~T}$ & $\%$ & $\mathrm{~T}$ & $\%$ & $\mathrm{~T}$ & $\%$ & & & & \\
\hline $\begin{array}{l}\text { Supporting good and } \\
\text { creative ideas for } \\
\text { developing } \\
\text { competitive } \\
\text { advantage }\end{array}$ & 22 & 40.0 & 13 & 23.6 & 11 & 20.0 & 7 & 12.7 & 2 & 3.6 & 3.84 & 1.20 & Agree & 1 \\
\hline $\begin{array}{lr}\text { Participating } & \text { its } \\
\text { management } & \text { with } \\
\text { information } & \end{array}$ & 18 & 40.0 & 13 & 23.6 & 15 & 27.3 & 7 & 12.7 & 2 & 3,6 & 3.69 & 1.17 & Agree & 3 \\
\hline $\begin{array}{ll}\text { Turning } & \text { tacit } \\
\text { knowledge } & \text { into } \\
\text { explicit one } & \end{array}$ & 12 & 21.8 & 21 & 38.2 & 12 & 21.8 & 8 & 14.5 & 2 & 3.6 & 3.60 & 1.10 & Agree & 4 \\
\hline $\begin{array}{l}\text { Setting a suitable } \\
\text { budget for supporting } \\
\text { knowledge } \\
\text { management projects }\end{array}$ & 15 & 27.3 & 14 & 25.5 & 4 & 7.3 & 17 & 30.9 & 5 & 9.1 & 3.31 & 1.40 & $\begin{array}{l}\text { Fairly } \\
\text { agree }\end{array}$ & 6 \\
\hline $\begin{array}{l}\text { Trying to develop } \\
\text { knowledge assets }\end{array}$ & 15 & 27.3 & 13 & 23.6 & 11 & 20.0 & 14 & 25.5 & 2 & 3.6 & 3.45 & 1.24 & Agree & 5 \\
\hline $\begin{array}{l}\text { Spreading culture of } \\
\text { individual and } \\
\text { collective initiative } \\
\text { among employees }\end{array}$ & 18 & 32.7 & 18 & 32.7 & 10 & 18.2 & 7 & 12.7 & 2 & 3.6 & 3.78 & 1.15 & Agree & 2 \\
\hline & $\mathrm{Av}$ & ge $\mathrm{m}$ & n: 3. & 1; Agre & & & & & & & & & & \\
\hline
\end{tabular}

Table 5 shows the percentages, repetitions, arithmetic means, and standard deviations for the axis of knowledge management operations. On the basis of the average mean that reached 3.61, it was concluded that the study participants agree with the statements of this axis.

The statements were regressively arranged on the basis of arithmetic means. It was found that the statement "Supporting good and creative ideas for developing competitive advantage" corresponded to the highest mean (3.84) and a prevailing opinion of "agree." Further, the statement "Setting a suitable budget for supporting knowledge management projects" corresponded to the lowest mean (3.31) and a prevailing opinion of "fairly agree." 


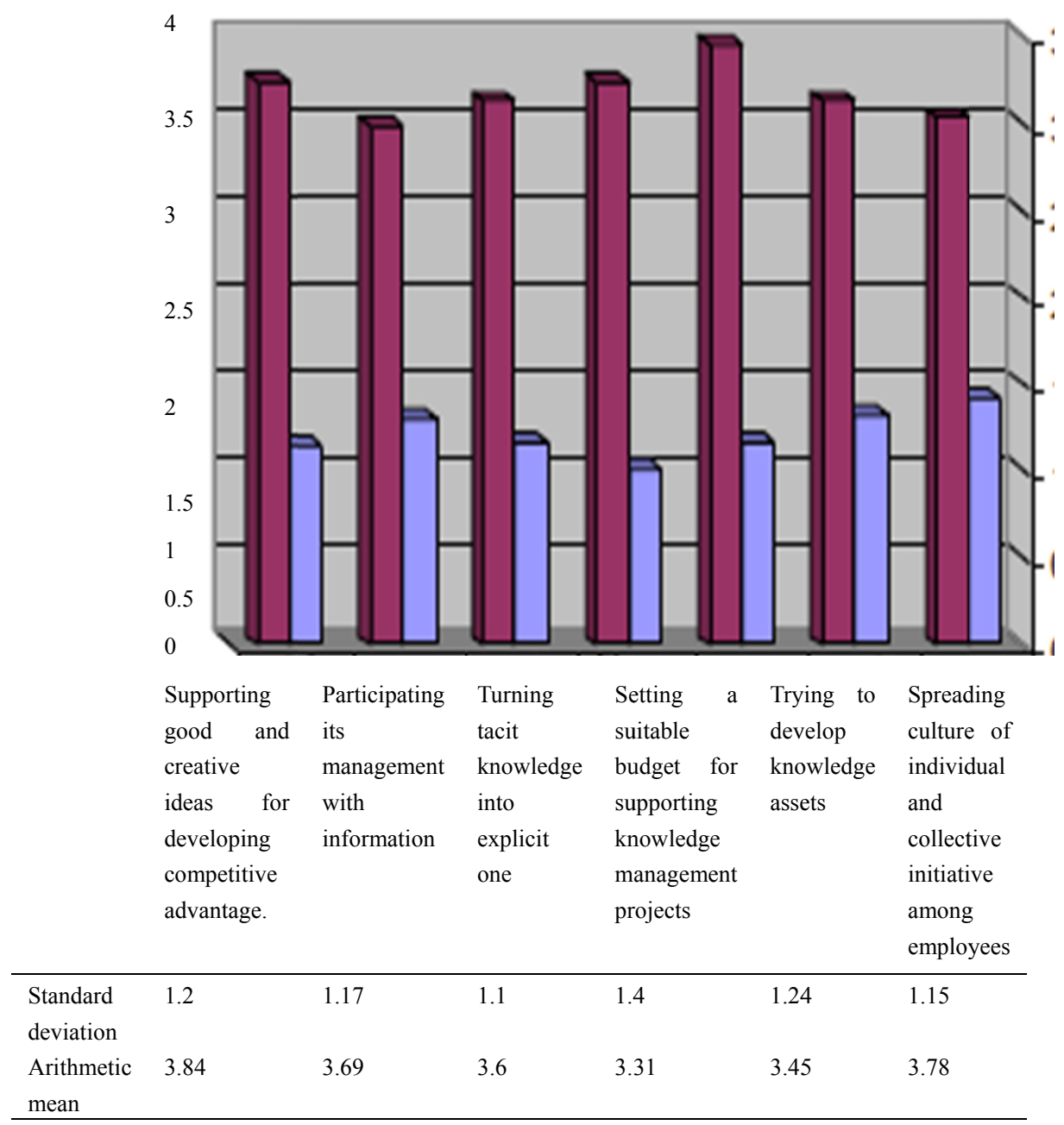

Figure 4. Different percentages, repetitions, arithmetic means, and standard deviations for axis (knowledge management operations)

Table 6. Different percentages, repetitions, arithmetic means, and standard deviations for axis (concept of organizing and estimating knowledge regarding HR employees)

\begin{tabular}{|c|c|c|c|c|c|c|c|c|c|c|c|c|c|c|}
\hline \multirow[t]{2}{*}{ Statement } & \multicolumn{2}{|c|}{$\begin{array}{l}\text { Totally } \\
\text { agree }\end{array}$} & \multicolumn{2}{|c|}{ Agree } & \multicolumn{2}{|c|}{$\begin{array}{l}\text { Fairly } \\
\text { agree }\end{array}$} & \multicolumn{2}{|c|}{ Disagree } & \multicolumn{2}{|c|}{$\begin{array}{l}\text { Totally } \\
\text { disagree }\end{array}$} & \multirow[t]{2}{*}{ Mean } & \multirow[t]{2}{*}{$\begin{array}{l}\text { The } \\
\text { Standard } \\
\text { deviation }\end{array}$} & \multirow[t]{2}{*}{$\begin{array}{l}\text { Agreement } \\
\text { level }\end{array}$} & \multirow[t]{2}{*}{$\begin{array}{l}\text { Serial } \\
\text { number }\end{array}$} \\
\hline & $\mathrm{T}$ & $\%$ & $\mathrm{~T}$ & $\%$ & $\mathrm{~T}$ & $\%$ & $\mathrm{~T}$ & $\%$ & $\mathrm{~T}$ & $\%$ & & & & \\
\hline $\begin{array}{l}\text { Providing an effective } \\
\text { IT system }\end{array}$ & 17 & 30.9 & 22 & 40.0 & 10 & 18.2 & 3 & 5.5 & 3 & 5.5 & 3.85 & 1.10 & Agree & 3 \\
\hline $\begin{array}{l}\text { Trying to estimate } \\
\text { knowledge assets }\end{array}$ & 9 & 16.4 & 27 & 49.1 & 12 & 21.8 & 5 & 9.1 & 2 & 3,6 & 3.65 & 0.99 & Agree & 6 \\
\hline $\begin{array}{lr}\text { Organizing } & \text { and } \\
\text { categorizing } & \text { available }\end{array}$ & & & & & & & & & & & & & & \\
\hline $\begin{array}{l}\text { knowledge and storing } \\
\text { it for easy collection } \\
\text { and grouping }\end{array}$ & 21 & 38.2 & 19 & 34.5 & 12 & 21.8 & 1 & 1.8 & 2 & 3.6 & 4.02 & 1.01 & Agree & 1 \\
\hline Giving regular and & & & & & & & & & & & & & & \\
\hline $\begin{array}{l}\text { limited explanations on } \\
\text { information }\end{array}$ & 15 & 27.3 & 25 & 45.5 & 10 & 18.2 & 3 & 5.5 & 2 & 3.6 & 3.87 & 1.00 & Agree & 2 \\
\hline $\begin{array}{l}\text { Defining higher levels } \\
\text { of all coefficients }\end{array}$ & 12 & 21.8 & 24 & 43.6 & 14 & 25.5 & 3 & 5.5 & 2 & 3.6 & 3.75 & 0.99 & Agree & 4 \\
\hline $\begin{array}{l}\text { Designing levels of } \\
\text { doing a job based on } \\
\text { knowledge integrity }\end{array}$ & 17 & 30.9 & 16 & 29.1 & 14 & 25.5 & 6 & 10.9 & 2 & 3.6 & 3.73 & 1.13 & Agree & 5 \\
\hline & Ave & age me & n: 3. & $1 ;$ Agr & & & & & & & & & & \\
\hline
\end{tabular}


Table 6 shows percentages, repetitions, arithmetic means, and standard deviations for the axis, i.e., the concept of organizing and estimating knowledge regarding HR employees.

On the basis of the average mean that reached 3.81, it was concluded that the study participants agree with the statements of the axis.

The statements were regressively arranged on the basis of arithmetic means. It was found that the statement "Organizing and categorizing available knowledge and storing it for easy collection and grouping" corresponded to highest mean (4.02) with a prevailing opinion of "agree." Further, the statement "Trying to estimate knowledge assets" corresponded to the lowest mean (3.65) with a prevailing opinion of "agree."

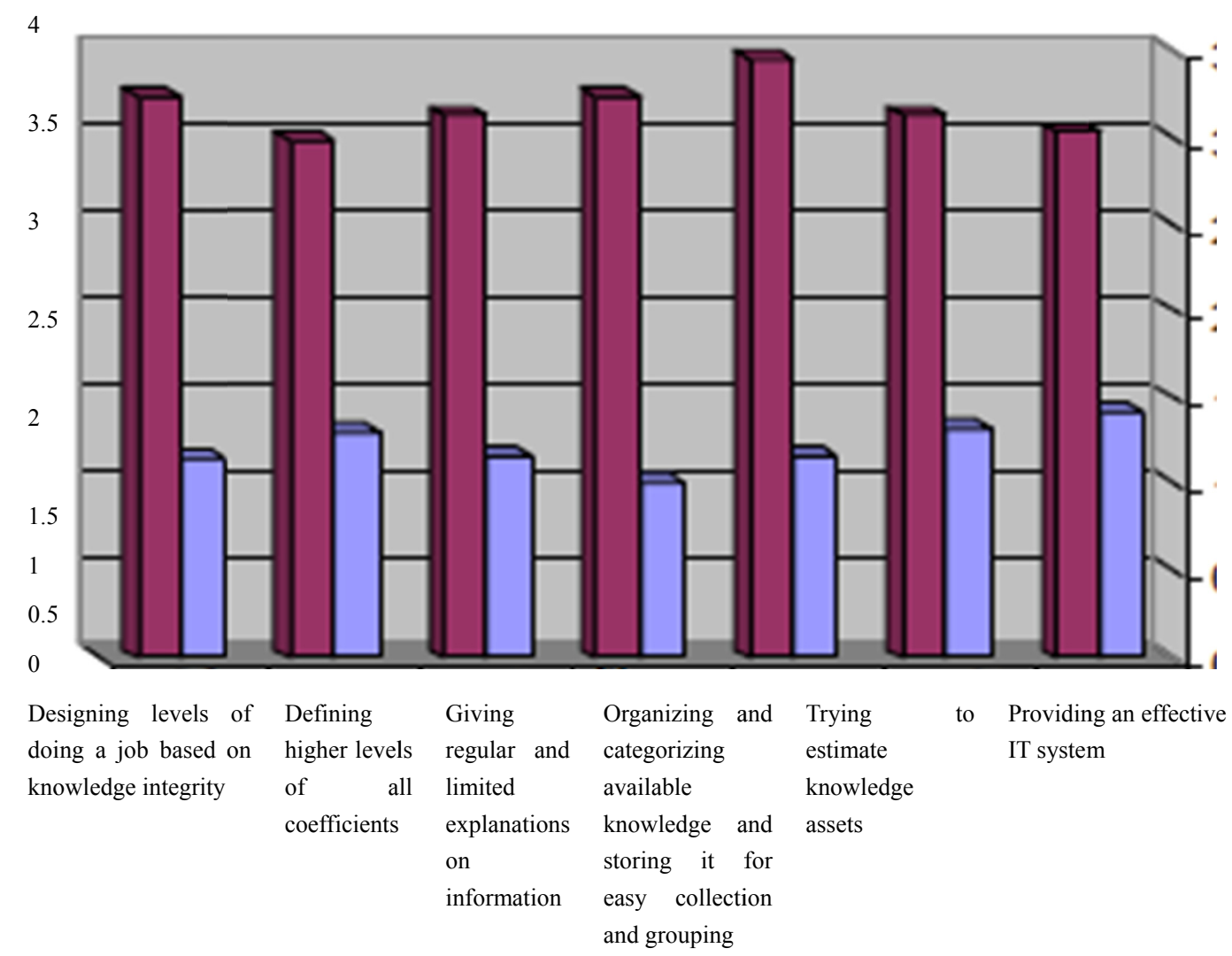

Figure 5. Arithmetic means and standards deviations for axis (concept of organizing and estimating knowledge regarding HR employees)

Table 7. Relation between study axes

\begin{tabular}{lllll}
\hline & $\begin{array}{l}\text { HR division in } \\
\text { Saudia work on }\end{array}$ & $\begin{array}{l}\text { Knowledge } \\
\text { management } \\
\text { concept regarding } \\
\text { HR employees }\end{array}$ & $\begin{array}{l}\text { Knowledge } \\
\text { management } \\
\text { operations }\end{array}$ & $\begin{array}{l}\text { Concept of organizing and } \\
\text { estimating knowledge } \\
\text { HR employees }\end{array}$ \\
\hline $\begin{array}{l}\text { HR division in Saudia work on } \\
\text { Knowledge management concept } \\
\text { regarding HR employees }\end{array}$ & $\begin{array}{l}0.891^{* *} \\
\text { Knowledge } \quad \text { management } \\
\text { operations } \\
\text { Concept of organizing and } \\
\text { estimating knowledge regarding } \\
\text { HR employees }\end{array}$ & 1 & $0.797^{* *}$ & $0.584^{* *}$ \\
0
\end{tabular}

Table 7 shows the relations between the study axes. On the basis of correlation values, we find that there is a 
relation among the different study axes at a statistical level $(0.01)$.

\section{Results}

The system tries to encourage the users to imitate the best practices of other organizations.

The system relates most of the special policies and procedures of knowledge management.

The study participants fairly agree upon the axis of the work for the HR division in Saudia.

The managers believe that the success of knowledge is based on organizational culture.

Knowledge management is considered information management.

The study participants fairly agree upon the axis of the knowledge management concept regarding HR employees.

Good and innovative ideas are advocated for developing a competitive advantage.

A culture of individual and group initiatives should be developed among employees.

The study participants agree upon the axis of knowledge management operations.

Available data and information are organized and categorized and then stored for easy collection and grouping.

Limited and regular explanations on information are made.

The study participants agree upon the concept of organizing and estimating knowledge regarding HR employees.

A relation exists between the different study axes at a statistical level (0.01).

\section{Conclusion and Recommendations}

Considerable attention should be paid upon knowledge management by the Saudia management because it is the only factor that can propel it toward the future. Through knowledge management, Saudia can make great leaps in technical, information, strategic, and economic aspects to compete with other organizations.

A system should be developed for imitating other organizations that have applied the knowledge management concept in the past. This can be used for organizing training programs for the staff, so that everyone benefits from such training. Outdoor training is important for making employees more experienced and efficient.

An organizational culture in knowledge management should be developed for employees via lectures, symposiums, conferences, and workshops. Employees should be committed to do researches on knowledge management, which will enable them to practice the knowledge management culture.

Awareness should be crated about the experiences of organizations specialized in the knowledge management field by utilizing all available means to learn and teach via the Internet. These experiences should be shared and practiced not only by Saudia but by all other Saudi and world organizations.

The concept of spreading knowledge between different Saudia administrations should be strengthened, thereby giving them strategic importance for future plans. In addition, this concept should be imparted to the targets of Saudia in order to realize the latest scientific and cognitive developments.

\section{References}

Al-Gharib, F. S. (2000). The knowledge management. The series of information bridge. Diwan of civil service: Kuwait.

Al-Khalidi, I. B. (2011). The administration dictionary. Amman: Dar Osama for publishing and distribution.

Al-Otaibi, Y. A. (1427). The knowledge management and applying it in the Saudi Universities: Applied study on Umm Al-Qura University. A not published master thesis: Umm Al-Qura University.

Al-Qubaisi, S. (2011). The knowledge management. Cairo: the Arab administrative development organization.

Al-Sabbagh, E. (2002). The knowledge management and its role in building the information community.

Bontis, N. (1999). Managing organizational knowledge by diagnosing intellectual capital: Framing and advancing the state of the field. International Journal of Technology Management, 18(5-8), 433-462.

Bryson, J. (2003). The strategic planning of public and nonprofit organizations. Lebanon: Lebanon Bookshop.

Donovan, A. M. (2008). Effectively Managing The $21^{\text {st }}$ Century Knowledge Worker. Journal of Knowledge Management Practice, 9(1), 14-16.

Hegazy, H. A. (2005). Knowledge Management: theoretical introduction. Beirut: the local Bookshop. 
Hislop, D. (2003). Linking human resource management and knowledge management via commitment: A review and research agenda. Employee Relations, 25(2),182-202.

Mehrdad G. (2011). Knowledge Management and Transformational Leadership in Organizational Success. International Journal of Information and Education Technology, 1(5), 377-379.

Negm, N. A. (1425). Book review: post knowledge management (pp. 709-724). Riyadh.

The Guide of the Saudi Airlines for Systems and Administrative Procedures (2014). Human resources sector.

\section{Copyrights}

Copyright for this article is retained by the author(s), with first publication rights granted to the journal.

This is an open-access article distributed under the terms and conditions of the Creative Commons Attribution license (http://creativecommons.org/licenses/by/3.0/). 